\title{
Experimental transmission of White Spot Syndrome Virus (WSSV) from crabs to shrimp Penaeus monodon
}

\author{
Panan Kanchanaphum ${ }^{1}$, Chainarong Wongteerasupaya ${ }^{4}$, \\ Nusra Sitidilokratana ${ }^{5}$, Vichai Boonsaeng ${ }^{1, *}$, Sakol Panyim ${ }^{1}$, \\ Anchalee Tassanakajon ${ }^{6}$, Boonsirm Withyachumnarnkul ${ }^{2}$, T. W. Flegel ${ }^{3}$ \\ 'Department of Biochemistry, ${ }^{2}$ Department of Anatomy, ${ }^{3}$ Department of Biotechnology, Faculty of Science, \\ Mahidol University, Rama VI Road, Bangkok 10400, Thailand \\ ${ }^{4}$ Department of Biochemistry, Faculty of Medicine, Srinakharinwirot University, Sukhumvit 23, Bangkok 10110, Thailand \\ ${ }^{5}$ National Center for Genetic Engineering and Biotechnology, Bangkok 10400, Thailand \\ ${ }^{6}$ Department Biochemistry, Faculty of Science, Chulalongkorn University, Phyathai Road, Bangkok 10330, Thailand
}

\begin{abstract}
White spot syndrome virus (WSSV) of the black tiger prawn Penaeus monodon is a recently discovered baculo-like virus disease which is currently the cause of very serious and widespread losses in the shrimp industry in Thailand and elsewhere in Asia. Three suspected crab carriers of this virus commonly found in shrimp-rearing areas were investigated. These were Sesarma sp. Scylla serrata and Uca pugilator. All these crabs could be infected with WSSV by injection and they sustained heavy viral infections for up to $45 \mathrm{~d}$ (confirmed by normal histology, specific in situ DNA hybridization and PCR amplification) without visible signs of disease or mortality. All of them also transferred the disease to $P$. monodon via water while physically separated in aquarium cohabitation tests. Transfer of the virus to the shrimp was monitored using in situ DNA hybridization and PCR assay at $12 \mathrm{~h}$ intervals after cohabitation began. With U. pugilator, WSSV could be detected in the shrimp cohabitants after $24 \mathrm{~h}$ using PCR amplification and after $60 \mathrm{~h}$ using in situ hybridization. With S. serrata, the shrimp were positive for WSSV after $36 \mathrm{~h}$ using PCR and after $60 \mathrm{~h}$ using DNA in situ hybridization. With Sesarma sp. they were positive after $48 \mathrm{~h}$ using PCR and $72 \mathrm{~h}$ using in situ hybridization. These laboratory studies demonstrated that crab carriers of WSSV may pose a real threat to cultivated shrimp. However, the studies were carried out in containers with a small volume and with relatively clean sea water as compared to shrimp cultivation ponds. Pond-based studies are now needed to determine whether factors such as pond volume, pond water quality and shrimp and crab behavior can influence the rate and success of transfer.
\end{abstract}

KEY WORDS: White spot syndrome virus WSSV - Penaeus monodon Sesarma sp. U Uca pugilator Scylla serrata

\section{INTRODUCTION}

Black tiger shrimp culture in Thailand has expanded tremendously in the past few years and the country has become the world's leading producer of cultivated shrimp (Rosenberry 1997). Although the industry is undergoing rapid development in a number of Asian countries, successful production is increasingly ham-

-Addressee for correspondence. E-mail: scvbs@mahidol.ac.th pered by many factors, including environmental pollution, poor management and disease (Flegel et al. $1995 \mathrm{a}$, bj. Of the infectious diseases, bacterial and viral agents, either as single or multiple pathogens, have caused most of the production losses (Flegel 1997).

White spot syndrome virus (WSSV) presently overshadows all other disease agents as the leading cause of production losses (Flegel 1997, Flegel et al. 1997). It was first reported in Thailand as an accidental infection in laboratory-reared shrimp in early 1994 (Wongteerasu- 
paya et al. 1995), but the first farm infections were not reported until late 1994 (Wongteerasupaya et al. 1996). At that time, the virus was compared to viruses of the Baculoviridae and to the subfamily of the non-occluded baculoviruses, the Nudibaculoviridae (Francki et al. 1991). In a subsequent report of the International Commission for Taxonomy of Viruses (ICTV) (Murphy et al. 1995), this classification was canceled and the viruses were left unassigned. However, to avoid confusion, we will use the old designation (Francki et al. 1991) for WSSV as a non-occluded baculovirus. The field signs of WSSV infection are rapid and massive mortality with diseased shrimp showing white spots 5 to $6 \mathrm{~mm}$ or more in diameter which remain embedded in the cuticle when it is removed. The spots are sometimes accompanied by a general reddish coloration of the whole shrimp body. Since late 1994, there have been increasing numbers of field reports of massive shrimp mortality associated with WSSV in several species of penaeid shrimp (Takahashi et al. 1994, Chou et al, 1995, Durand et al. 1996, Lo et al. 1996a, Wongteerasapaya et al. 1996, Peng et al. 1997). The disease has also been detected in a wide range of wild crustaceans, including, crabs, lobsters, and shrimp (penaeid and non-penaeid) by DNA diagnostic techniques (Lo et al. 1996a, b, Maeda et al. 1997, Peng et al. 1997). However, detection alone, especially by histology and polymerase chain reaction (PCR) technology, cannot be used to confirm whether tested animals are actively infected with the virus or just mechanical carriers. In situ DNA hybridization tests (Wongteerasupaya et al. 1996) and studies with the electron microscope have been used to establish that some of the suspected carriers actually have active viral infections. However, even if infections are confirmed, it cannot be automatically concluded that the infected animals can transmit the virus to cultivated shrimp. Information regarding the incidence of natural carriers and the potential risk they pose is of vital importance to shrimp farmers, if they are to institute effective measures to prevent viral infections without undue expense. Unpublished studies in Thailand (B. Withyachumnarnkul) implicated several common crab species as WSSV carriers in feeding trials with shrimp. Some of the suspected species and genera corresponded to those captured and found to be PCR positive for WSSV in Taiwan (Lo et al. 1996b) and Japan (Maeda et al. 1997). In addition, Supamattaya et al. (1998) have shown that crabs can be infected with WSSV by feeding on infected shrimp tissue, by immersion in water containing viral extracts and by injection. Therefore, the purpose of this study was to determine whether 3 suspected carrier crab species commonly found in shrimp-rearing areas of Thailand could successfully transfer the viral disease to Penaeus monodon in laboratory tests.

\section{MATERIALS AND METHODS}

Shrimp and crab specimens. Normal Penaeus monodon (approximately $20 \mathrm{~g}$ each) were collected from a shrimp farm in Thailand. All were maintained in aerated aquaria at 30 to $35^{\circ} \mathrm{C}$ and fed on a dry commercial shrimp feed diet twice daily. Three adult crab species, i.e. Sesarma sp. (approximately $30 \mathrm{~g}$ each), the mud crab Scylla serrata (approximately $300 \mathrm{~g}$ each), and the fiddler crab $U_{c a}$ pugilator (approximately $30 \mathrm{~g}$ each), were collected from shrimp culture areas in the central region of Thailand. Crabs were maintained in aquaria under conditions similar to those for the shrimp, except that they were not completely submerged, and they were fed the same diet regimen. Haemolymph samples $(50 \mu \mathrm{l}$ for smears and $5 \mu \mathrm{l}$ for $\mathrm{PCR}=$ total $55 \mu \mathrm{l}$ ) could be drawn from the shrimp or crabs at $12 \mathrm{~h}$ intervals without causing mortality.

In situ DNA hybridization. The DNA probe for WSSV was prepared from laboratory-infected shrimp as previously described (Wongteerasupaya et al. 1995). It was non-radioactively labeled with digoxigenin using the random prime method, following the instructions accompanying the Boehringer Mannheim kit.

In situ hybridization with tissue sections was carried out as previously described (Wongteerasupaya et al. 1996). For in situ hybridization with shrimp and crab haemolymph, Davidson's fixative was modified by the replacement of acetic acid with distilled water. The fixative was held in a syringe at twice the volume $(100 \mu \mathrm{l})$ of the haemolymph to be drawn $(50 \mu \mathrm{l})$. After drawing the haemolymph, it was immediately mixed thoroughly with the fixative and then smeared on Fisher plus microscope slides (Fisher Scientific) and left to air dry. The method for in situ hybridization was then carried out as instructed in the Boehringer Mannheim Genius kit manual with the following modifications. Haemolymph smears were immersed in PBH buffer $(8 \mathrm{~g}$ $\mathrm{NaCl}, 0.2 \mathrm{~g} \mathrm{KCl}, 1.44 \mathrm{~g} \mathrm{Na}_{2} \mathrm{HPO}_{4}, 0.24 \mathrm{~g} \mathrm{KH} \mathrm{PO}_{4}$ in $1 \mathrm{l}$ distilled water adjusted to $\mathrm{pH} 7.4$ with $1 \mathrm{~N} \mathrm{HCl}$ ) for $5 \mathrm{~min}$. They were then removed, air dried and heated at $95^{\circ} \mathrm{C}$ for $10 \mathrm{~min}$ before the addition of 20 to $25 \mu \mathrm{l}$ probe cocktail $(50 \times$ Denhart's Solution, $50 \% \mathrm{w} / \mathrm{v}$ dextran sul-

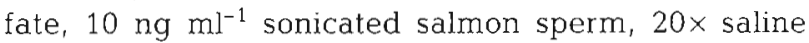
sodium citrate, SSC, $50 \%$ formamide, $10 \mathrm{ng} \mathrm{ul}^{-1}$ digoxigenin-labelled probe). The slides were then heated at $96^{\circ} \mathrm{C}$ for $6 \mathrm{~min}$. After quick cooling on ice for $1 \mathrm{~min}$, they were placed in a humid chamber and allowed to hybridize overnight at $42^{\circ} \mathrm{C}$. Subsequent processing for blocking and detection were as described in the manual. The slides were then counterstained for 1 min with $0.5 \%$ Bismark brown, dehydrated and mounted with Permount (Fisher Scientific). There was no protease treatment step in the haemolymph protocol. since this was found to yield false negative results. 
PCR amplification tests. Haemolymph samples $(5 \mu \mathrm{l})$ were heated in $0.5 \mathrm{ml}$ Eppendorf tubes at $95^{\circ} \mathrm{C}$ for 10 min (until dry). For amplification, $50 \mu \mathrm{l}$ of PCR reaction mixture was added (PCR buffer pH 9.0, 1.5 mM $\mathrm{MgCl}_{2}, 1 \mathrm{mM}$ of each deoxynucleotide triphosphate, $1 \mu \mathrm{M}$ of each primer and 2 units of Taq DNA polymerase). PCR primers were prepared based on the sequence of a specific probe described by Wongteerasapaya et al. (1996). These primers yielded a 294 base pair (bp) fragment specific for WSSV DNA. The PCR mixture was overlaid with $50 \mu$ l of mineral oil to prevent evaporation. The reaction was then carried out for 35 cycles of denaturation, annealing, and polymerization. The first cycle included heat denaturation at $90^{\circ} \mathrm{C}$ for $3 \mathrm{~min}$, annealing at $60^{\circ} \mathrm{C}$ for $30 \mathrm{~s}$, and polymerization at $72^{\circ} \mathrm{C}$ for $30 \mathrm{~s}$. The next 33 cycles used heat denaturation at $90^{\circ} \mathrm{C}$ for $30 \mathrm{~s}$, annealing at $60^{\circ} \mathrm{C}$ for $30 \mathrm{~s}$ and polymerization at $72^{\circ} \mathrm{C}$ for $30 \mathrm{~s}$. For the last cycle, the heat denaturation temperature was $90^{\circ} \mathrm{C}$ for $30 \mathrm{~s}$, annealing was $60^{\circ} \mathrm{C}$ for $30 \mathrm{~s}$, and polymerization was $72^{\circ} \mathrm{C}$ for $5 \mathrm{~min}$. Amplified products were detected by electrophoresis of $20 \mu \mathrm{l}$ aliquots through $1.5 \%$ agarose gel in TBE buffer.

H\&E staining. Haemolymph samples were mixed with modified Davidson's fixative (2:1) and smeared on slides as described above. After air drying, they were immersed in Mayer's Haematoxylin (5 to $10 \mathrm{~min}$ ) and then rinsed with tap water for $15 \mathrm{~min}$. Next, they were stained with eosin ( $5 \mathrm{~min}$ ), dehydrated with an ethanol series, transfered to xylene and mounted in permount (Fisher Scientific). Whole moribund shrimp (counted as dead when removed) and crab specimens at the end of the tests were preserved in Davidson's fixative and processed for normal histology as described by Bell \& Lightner (1988).

Experimental transmission tests. Before tests were performed, haemolymph samples of experimental animals (shrimp and crab) were first assayed for WSSV by PCR assay to assure that they had no detectable infection. Preliminary tests were performed in which the crabs were experimentally infected with WSSV by injection of $100 \mu$ l of viral suspension. The viral suspension was prepared by dilution of haemolymph harvested from experimentally WSSV infected shrimp in lobster haemolymph buffer (LHB) (Boonyaratpalin et al. 1993). Injected viral suspensions contained approximately $2.7 \times 10^{4}$ virions as measured by standardized PCR against quantified dilutions of purified viral DNA and considering the viral genome to be $168 \mathrm{kbp}$ (Wongteerasupaya et al. 1995). For each species of crab, 7 individuals were injected with WSSV and 7 were not. They were then followed for $45 \mathrm{~d}$ with periodic individual sampling of the haemolymph $(5 \mu l)$ for PCR assays. At Day 45 they were sacrificed, fixed in Davidson's fixative and examined histologically and for WSSV.
For transmission tests, 3 experimentally infected crabs of each species (separate from the crabs described above and also verified WSBV negative by PCR) were placed ( $96 \mathrm{~h}$ post injection) in aquaria $(70 \times$ $30 \times 40 \mathrm{~cm}$ ) at $27^{\circ} \mathrm{C}$ with 10 uninfected shrimp (verified by PCR) but separated from them by a wire mesh. Haemolymph samples $(5 \mu l)$ were drawn from each shrimp at $12 \mathrm{~h}$ intervals and assayed for WSSV using PCR. Mortality was recorded for both crabs and shrimp in all experiments. Controls comprised uninfected crabs cohabitant (but separated by a wire cage) in aquaria with 10 uninfected shrimp.

\section{RESULTS}

\section{Experimental crab infections}

All 3 crab species could be infected with WSSV by injection. The haemolymph of individual crabs of all 3 species was sampled every $12 \mathrm{~h}$ for the first $108 \mathrm{~h}$, then at daily intervals thereafter for $45 \mathrm{~d}$ after injection. The virus was first clearly detected by means of PCR analysis of haemolymph samples from Uca pugilator at $24 \mathrm{~h}$ (Fig. 1a), but later for Scylla serrata ( 36 hi Fig. 1b) and Sesarma sp. (48 $h_{i}$ Fig. 1c). The intensity of the first visible PCR band at $48 \mathrm{~h}$ for Sesarma sp. was weak and did not photograph well. A very clear band was not evident until $72 \mathrm{~h}$ and onwards. The gels in the figures show the results for samples up to 96 h only, but later samples also gave PCR bands of high intensity, indicating relatively high levels of infection. In contrast to $\mathrm{PCR}$, a much longer time was required before the virus could be detected by in situ DNA hybridization using haemolymph smears (see Table 1). Representative examples of positive and negative in situ hybridization reactions and histopathology by H\&E staining of gills are shown in Fig. 2 for $U$. pugilator only, but results for the other crab species were similar. H\&E staining of haemocytes did not reveal any differences between normal and infected crabs. No positive PCR results, in situ hybridization results or WSSV histopathology were obtained with the control crabs which were not injected with WSSV. There were no mortalities among

Table 1. Uca pugilator, Scylla serrata and Sesarma sp. Time post injection for detection of WSSV in infected crabs using 2 methods. The crab haemolymph was sampled every $12 \mathrm{~h}$

\begin{tabular}{|c|c|c|}
\hline Crab species & $\begin{array}{l}\text { Time post injection } \\
\text { PCR assay }\end{array}$ & $\begin{array}{l}\text { required for detection } \\
\text { In situ hybridization }\end{array}$ \\
\hline U. pugilator & $24 \mathrm{~h}$ & $60 \mathrm{~h}$ \\
\hline S. serrata & $36 \mathrm{~h}$ & $60 \mathrm{~h}$ \\
\hline Sesarma sp. & $48 \mathrm{~h}$ & $72 \mathrm{~h}$ \\
\hline
\end{tabular}


the control or virus-injected crabs over the 45 d observation period for these tests, although the infected crabs were PCR positive for WSSV throughout the period of observation (Fig. 3).

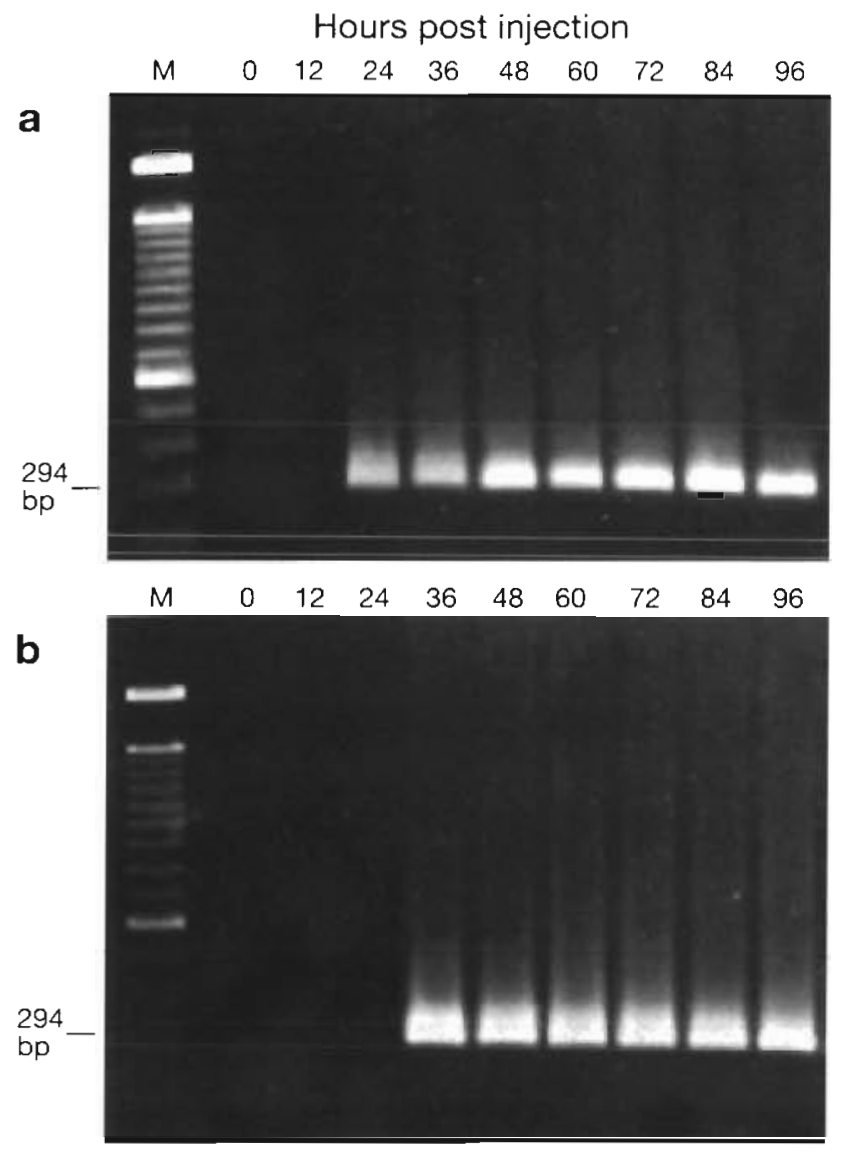

\section{Transmission experiments}

Shrimp kept as cohabitants with infected crabs began to die within $3 \mathrm{~d}$ with Uca pugilator, Scylla serrata

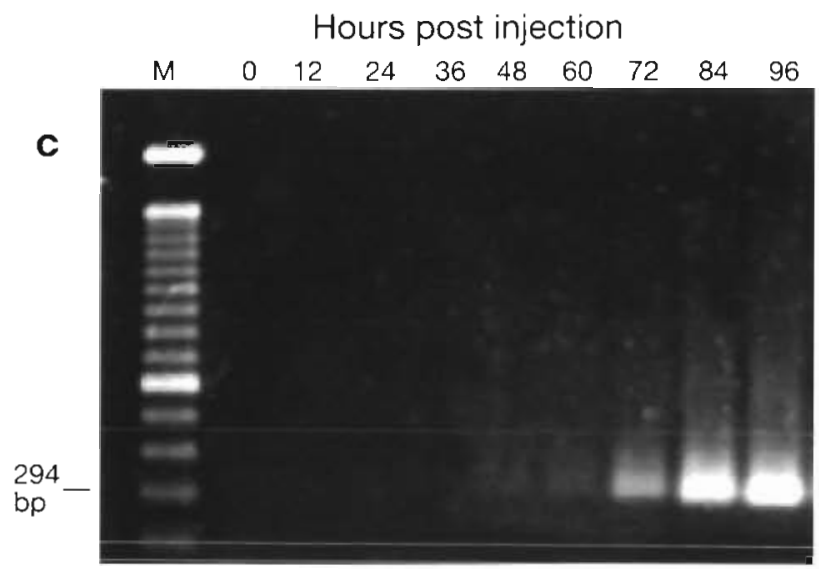

Fig. 1. Specific WSSV PCR product in crab haemolymph at various times post injection of WSSV into (a) Uca pugilator, (b) Scylla serrata and (c) Sesarma sp. Bands are clearly visible for $U$. pugilator from $24 \mathrm{~h}$ onwards and for $S$. serrata from $36 \mathrm{~h}$ onwards. Faint bands were detectable on the gels for Sesarma sp. at 48 and $60 \mathrm{~h}$ but these did not photograph well. Very clear bands are visible from $72 \mathrm{~h}$ onwards. Lane M: $100 \mathrm{bp}$ DNA ladder; remaining lanes: PCR products from haemolymph at various times (h) post injection
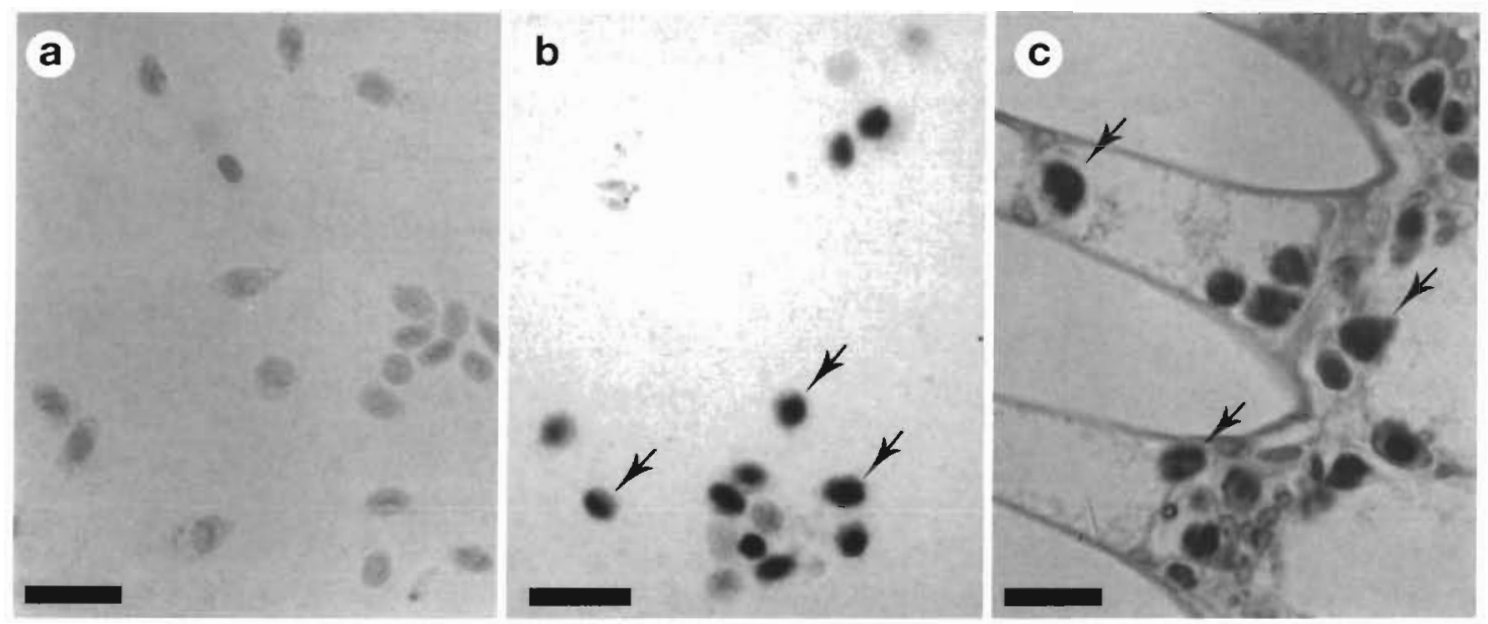

Fig. 2. In situ hybridization and H\&E staining of tissues from Uca pugilator (scale bars $=15 \mu \mathrm{m}$ ). (a) In situ hybridization of haemolymph from normal control $U$. pugilator at $60 \mathrm{~h}$, showing a negative hybridization reaction. (b) In situ hybridization of haemolymph from $U$. pugilator at $60 \mathrm{~h}$ after injection with WSSV, showing a positive hybridization reaction (dark staining nuclei, some marked by arrows). (c) H\&E staining of gill tissue from U. pugilator at $96 \mathrm{~h}$ post injection with WSSV (i.e. used as a shrimp cohabitant). Hypertrophied nuclei containing basophilic inclusions typical of WSSV histopathology are clearly visible (some marked by arrows) 


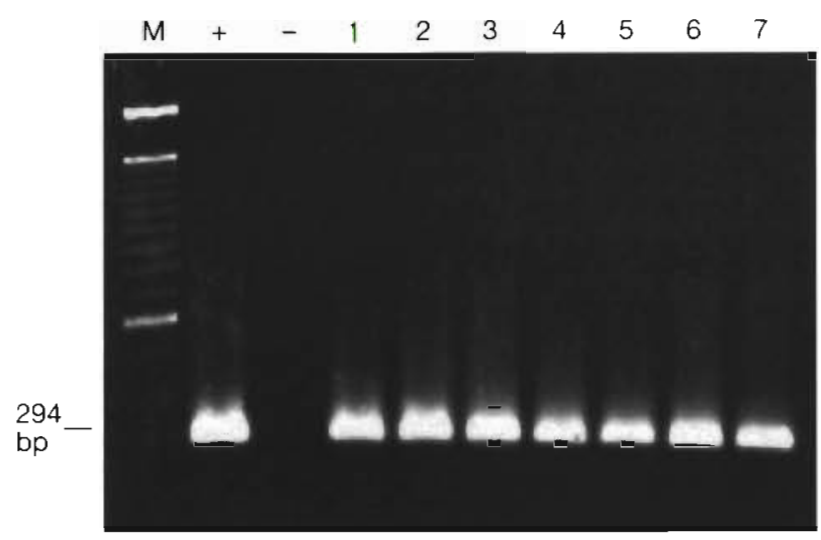

Fig. 3. Specific WSSV PCR product in haemolymph of 7 WSSVinjected Scylla serrata reared for $45 \mathrm{~d}$. Lane M: 100 bp DNA ladder; + : positive control ${ }_{i}-$ : negative control; lanes 1 to 7 : individual crabs

and Sesarma sp. (Table 2). The presence of WSSV could be detected by normal histology and in situ hybridization in moribund shrimp with results similar to those shown for $U$. pugilator in Fig. 2. There was no crab mortality over the $8 \mathrm{~d}$ period of the test, but examination of the WSSV crabs by PCR and in situ hybridization during the test (data not shown) and by normal histology at the end of the test (cf. Fig. 2) showed clear evidence of WSSV infection. With both the shrimp and the crabs, no differences could be seen between haemocytes of infected and uninfected animals by $H \& E$ staining. All of the shrimp died within $8 \mathrm{~d}$. There were no mortalities in the aquaria where uninfected crabs (PCR verified) were reared with uninfected shrimp (PCR verified) and all the animals remained PCR negative for WSSV throughout the period of the test. They were also histologically negative for WSSV at the end of the test.

Early detection of WSSV by PCR was possible using haemolymph from infected shrimp cohabitants (Table 2). Earliest detection was obtained when they were reared with infected Uca pugilator ( 36 hi Fig. 4a),

Table 2. Time to detection of WSSV and time to mortality for Penaeus monodon reared with various WSSV infected crab species. Ten shrimp were placed in each aquarium with 3 of each test crab species. Haemolymph was sampled and tested every $12 \mathrm{~h}$

\begin{tabular}{|lcccccccc|}
\hline $\begin{array}{l}\text { Crab } \\
\text { species }\end{array}$ & $\begin{array}{c}\text { Time to detection } \\
\text { in shrimp (h) } \\
\text { PCR In situ }\end{array}$ & \multicolumn{6}{c|}{$\begin{array}{c}\text { Shrimp mortality (no.) } \\
\text { at days post exposure }\end{array}$} \\
& 3d & $4 \mathrm{~d}$ & $5 \mathrm{~d}$ & $6 \mathrm{~d}$ & $7 \mathrm{~d}$ & $8 \mathrm{~d}$ \\
\hline Uca pugilator & 36 & 60 & 3 & 4 & 3 & & & \\
Scylla serrata & 48 & 60 & 3 & 1 & 3 & 1 & 2 & \\
Sesarma sp. & 48 & 72 & 2 & 3 & 2 & 1 & 0 & 2 \\
\hline
\end{tabular}

while the time with Scylla serrata and Sesarma sp. was longer ( $48 \mathrm{~h}$; Fig 4b, c, respectively). Detection before the onset of mortality was possible by in situ hybridization, but this was usually very close to the time for onset of mortality.
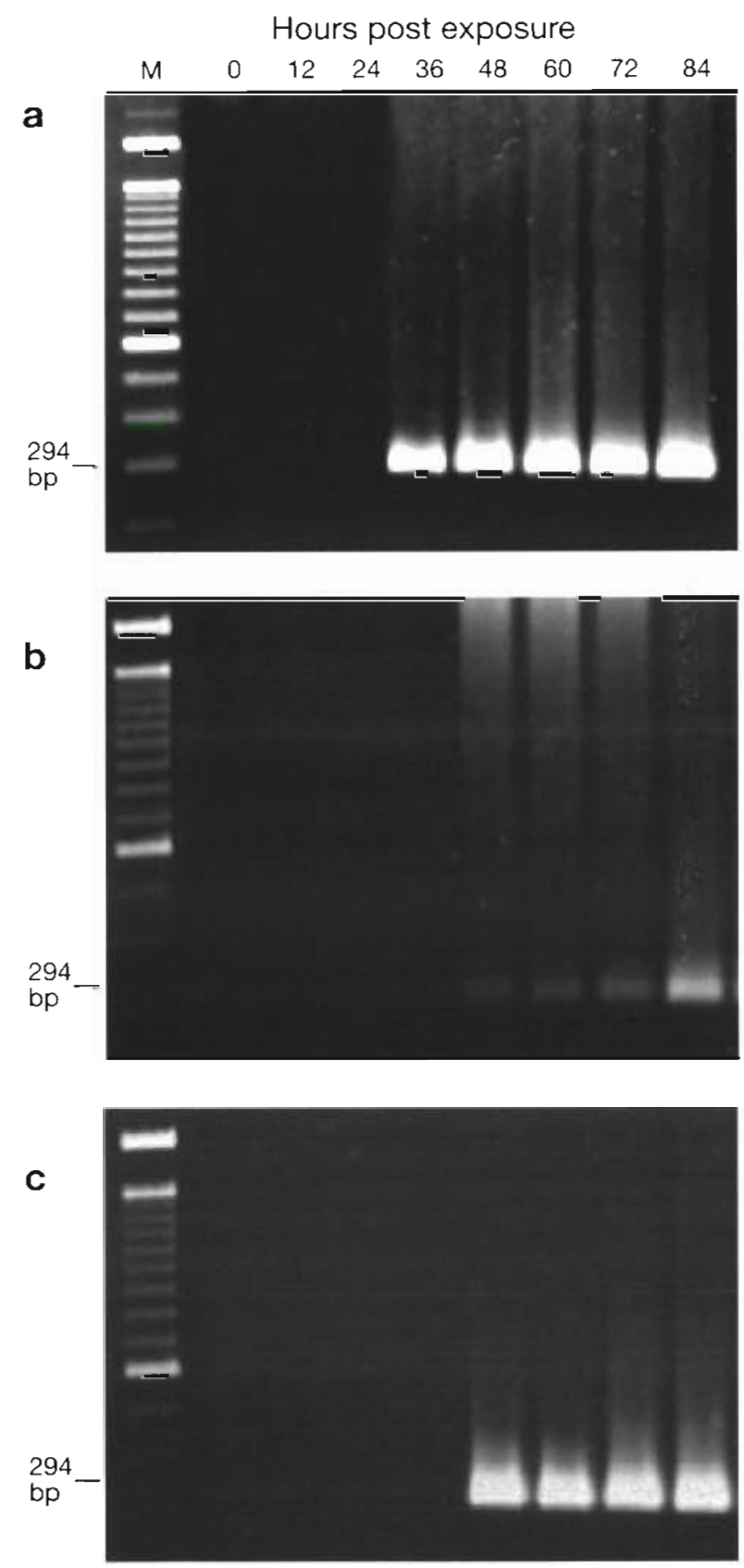

Fig. 4. Specific WSSV PCR product in haemolymph of Penaeus monodon at various times (h) after initiation of cohabitation with WSSV-infected (a) Uca pugilator, (b) Scylla serrata and (c) Sesarma $\mathrm{sp}$. Clear PCR amplicons are apparent with $U$. pugilator from $36 \mathrm{~h}$ onwards and for S. serrata and Sesarma from $48 \mathrm{~h}$ onwards. Lane $\mathrm{M}$ : $100 \mathrm{bp}$ DNA ladder; remaining lanes: PCR products from haemolymph sampled at various times (h) 


\section{DISCUSSION}

The results of the experiments described here clearly show that the 3 crab species studied can be infected with WSSV by injection. Once infected, they rapidly transferred the infection to Penaeus monodon. This augments the work of Lo et al. $(1996 \mathrm{a}, \mathrm{b})$, who reported that WSSV could be detected by PCR amplification in many crustacean carriers. The rapid experimental transmission of WSSV to $P$. monodon indicates that infected crabs in the shrimp farming environment could pose a serious threat to black tiger prawn farmers. The threat may apply to most of the shrimp cultivation industry, since WSSV also infects several other cultivated penaeid shrimp (Lightner 1996. Wongteerasupaya et al. 1996). In our study the infected crabs survived for $45 \mathrm{~d}$ without any mortality, showing that they can be actively infected with WSSV for extended periods without any mortality or gross signs of weakening. Supamattaya et al. (1998) also found this with Scylla serrata. Although the crabs in this study were infected by injection of WSSV, it has been shown that they can also be infected by immersion in WSSV contaminated sea water and by feeding on WSSV-infected shrimp (Supamattaya et al. 1998)

Because our tests were carried out in aquaria using relatively clean sea water, it is difficult to extrapolate to what might happen in an actual farm setting. Shrimp pond water contains a much more complex mixture of bacteria, phytoplankton and zooplankton than clean aquarium water. The dilution volume for viral particles escaping from a potential carrier is also much greater. These factors, along with behavior of the crabs and shrimp, would be important to consider in assessing the actual risk of viral transfer from crabs to shrimp in a real aquaculture setting. Further studies are necessary to establish the actual degree of risk. However, until there is reason to believe otherwise, the results of this study suggest that farmers would be well advised to prevent all crabs from entering their shrimp ponds throughout the cultivation cycle.

One startling feature of this work was the high degree of viremia in the crabs, as judged from the large numbers of infected cells seen in their tissues by histology and in situ hybridization and from the strong PCR amplification signals from their haemolymph. Yet they suffered no visible ill effects and no mortality during the period of observation. These results corresponded to those of Supamattaya et al. (1998), who also showed that crabs could carry heavy viral infections without visible negative effects. This contrasted with high mortality in Penaeus monodon at similar levels of viremia in the above authors' and in our tests. Clearly the crabs were not 'resistant' to the virus in the traditional sense, since they did not appear to clear it from their system or inactivate it. Rather they seemed to tolerate it at very high levels of replication. Nor did the virus appear to have lowered virulence for $P$. monodon after replication in the crabs. It is apparent that the level of viral replication, in itself, was not the cause of mortalities in the shrimp, and that some other mechanism would have to be invoked to explain it.

It is well known that insect baculoviruses process genes that inhibit apoptosis (IAP genes) (Clem et al. 1996) and that these genes allow viral replication to occur without initiating host cell death. WSSV is probably a baculo-like virus or related to the baculo-like viruses (Wongteerasupaya et al. 1995) and it may therefore contain IAP genes that function in some crustaceans but not others. Alternatively, it may be that the crabs have a high level of tolerance through prior adaptive accommodation to the same or a similar viral pathogen (Pasharawipas et al. 1997. Flegel \& Pasharawipas 1998). An understanding of the reasons for differences in mortality from equally heavy viral infections may allow us to develop strategies for limiting mortality from viral pathogens in shrimp aquaculture.

Acknowledgements. The authors thank the National Center for Genetic Engineering and Biotechnology of Thailand and the Thailand Research Fund for funds to carry out this work.

\section{LITERATURE CITED}

Bell TA, Lightner DA (1988) A handbook of normal penaeid shrimp histology. World Aquaculture Society, Baton. Rouge, LA

Boonyaratpalin S, Supamataya K, Kasornchandra J, Direkbusarakom S, Aekpanithanpong U, Chantanachookhin C (1993) Non-occluded baculo-like virus, the causative agent of yellow-head disease in the black tiger shrimp Penaeus monodon. Fish Pathol 28:103-109

Chou HY, Huang CY, Wang CH, Chiang HC, Lo CF (1995) Pathology of a baculovirus infection causing white spot syndrome in cultued penaeid shrimp in Taiwan. Dis Aquat Org 25:133-141

Clem RJ, Hardwick JM, Miller LK (1996). Anti-apoptotic genes of baculoviruses. Cell Death Differ 3:9-16

Durand S, Lightner DV, Nunan LM, Redman RM, Mari J. Bonami JR (1996) Application of gene probes as diagnostic tools for white spot baculovirus (WSSV) of penaeid shrimp. Dis Aquat Org 27:59-66

Flegel TW (1997) Special topic review: major viral diseases of the black tiger prawn (Penaeus monodon) in Thailand. World J Microbiol Biotechnol 13:433-442

Flegel TW, Boonyaratpalin S, Withyachumnarnkul B (1997) Progress in research on yellow-head virus and white-spot virus in Thailand. In: Flegel TW, MacRae I (eds) Diseases in Asian aquaculture III. Asian Fisheries Soc, Manila, p 285-296

Flegel TW, Fegan DF, Sriurairatana S (1995a) Environmental control of infectious shrimp diseases in Thailand. In: Shariff $M$, Subasinghe RP, Arthur JR (eds) Diseases in Asian aquaculture II. Asian Fisheries Soc, Manila, p 65-79 
Flegel TW, Pasharawipas T (1998) Viral accommodation: a new concept for crustacean response to viral pathogens. In: Flegel TW (ed) Advances in shrimp biotechnology. National Center for Genetic Engineering and Biotechnology, Bangkok (in press)

Flegel TW, Sriurairatana S, Wongterrasupaya C, Boonsaeng $V$, Panyim S. Withyachumnarnkul B (1995b) Progress in characterization and control of yellow-head virus of Penaeus monodon. In: Browdy CL. Hopkins JS (eds) Swimming through troubled water Proceedings of the Special Session on Shrimp Farming, Aquaculture'95. World Aquaculture Society, Baton Rouge, LA, p 76-83

Francki RIB, Fauquet CM, Knudson DL, Brown F (1991) Classification and nomenclature of viruses. Archives of virology. Springer-Verlag, Vienna

Lightner DV (1996) A handbook of shrimp pathology and diagnostic procedures for disease of cultured penaeid shrimp. World Aquaculture Society, Baton Rouge, LA

Lo CF, Ho CH, Peng SE, Chen CH, Hsu HC, Chiu YL, Chang CF, Liu KF, Su MS, Wang CH, Kou GH (1996a) White spot syndrome baculovirus (WSSV) detected in cultured and captured shrimp, crabs and other arthropods. Dis Aquat Org 27:215-225

Lo CF, Leu JH, Ho CH, Chen $\mathrm{CH}$, Peng SE, Chen YT, Chou $\mathrm{CM}$, Yen PY, Huang $\mathrm{CJ}$, Chou HY, Wang $\mathrm{CH}$, Kou $\mathrm{GH}$ (1996b) Detection of baculovirus associated with white spot syndrome (WSSV) in penaeid shrimps using polymerase chain reaction. Dis Aquat Org 25:133-141

Maeda $M$, Itami $T$, Kondo $M$, Henning $O$, Takahashi $Y$, Hirono I, Aoki T (1997) Charactenistics of penaeid rodshaped DNA virus of kuruma shrimp. In: Inui Y (ed) New approaches to viral diseases of aquatic animals. NRIA lnternational Workshop. Kyoto, Japan, National Research Institute of Aquaculture, Nasei, p 218-228

Murphy FA, Fauquet CM, Bishop DHL, Ghabrial SA, Jarvis AW, Martelli GP, Mayo MA, Summers MD (1995) Virus

Editorial responsibility: Otto Kinne,

Oldendorf/Luhe, Germany taxonomy. Archives of virology. Springer Verlag, Vienna Pasharawipas T, Flegel TW, Sriurairatana S, Morrison DJ (1997) Latent yellow-head infections in Penaeus monodon and implications regarding disease tolerance or resistance. In: Flegel TW, Menasveta P, Paisarnrat S (eds) Shrmp biotechnology in Thailand. National Center for Genetic Engineering and Biotechnology, Bangkok, p 45-53

Peng SE, Lo CF, Wang CH, Ho CH. Chang CF, Kou GH (1998) Detection of white spot baculovirus (WSBV) in giant freshwater prawn, Macrobrachium rosenbergii, using polymerase chain reaction. Aquaculture 164:253-262

Rosenberry B (1997) World shrimp farming 1996. Shrimp News International, San Diego, CA

Supamattaya K, Hoffmann RW, Boonyaratpalin S, Kanchanaphum P (1998) Experimental transmission of white spot syndrome virus (WSSV) from black tiger shrimp Penaeus monodon to the sand crab Portunus pelagicus, mud crab Scylla serrata and krill Acetes sp. Dis Aquat Org 32:79-85

Takahashi Y, Itami T, Kondo M, Maeda M, Fujii R, Tomanaga S, Supamattaya K, Boonyaratpalin S (1994) Electron microscopic evidence of bacilliform virus infection in kuruma shrimp (Penaeus japonicus). Gyobo Kenkyu (Fish Pathol) 29:121-125

Wongteerasupaya C, Vickers JE, Sriurairatana S, Nash GL, Akarajamorn A, Boonsaeng V, Panyim S, Tassanakajon A, Withyachumnarnkul B, Flegel TW (1995) A non-occluded, systemic baculovirus that occurs in cells of ectodermal and mesodermal origin and caused high mortality in the black tiger prawn Penaeus monodon. Dis Aquat Org 21:69-77

Wongteerasupaya $C$, Wongwisansri S, Boonseang $V$, Panyim S, Pratanpipat P, Nash GL, Withayachumnarnkul B, Flegel TW (1996) DNA fragment of Penaeus monodon baculovirus PmNOBII gives positive in situ hybridization with white-spot viral infections in six penaeid shrimp species. Aquaculture 143:23-32

Submitted: July 15, 1997; Accepted: June 23, 1998

Proofs received from author(s): August 13, 1998 